\title{
Recent seawater temperature histories, status, and predictions for Madagascar's coral reefs
}

\author{
Tim R. McClanahan ${ }^{1,2, *}$, Mebrahtu Ateweberhan ${ }^{2}$, Johnstone Omukoto ${ }^{2}$, Louis Pearson ${ }^{2}$ \\ ${ }^{1}$ Marine Program, Wildlife Conservation Society, 2300 Southern Boulevard, Bronx, New York 10460-1099, USA \\ ${ }^{2}$ Coral Reef Conservation Project, PO Box 99470, 80107 Mombasa, Kenya
}

\begin{abstract}
Recent temperature histories and benthic surveys of Madagascar's coral reefs are presented from 3 disparate regions in order to develop an understanding of the relationship between sea surface temperature (SST) and benthic cover, coral diversity, and community structure. Results indicate the presence of distinct temperature zones influenced by windward and seaward positions, latitude, intra- and inter-annual cycles, and local hydrodynamics. Southwest reefs had SSTs with the lowest mean, highest variation, fastest rise, strongest periodicities and highest cumulative degree heating weeks during recent warm events. These reefs were distinguished by a low number of coral taxa and a high cover of erect algae and had recently undergone a major decline in coral cover and change in community structure. Northwestern and eastern reefs had SSTs with moderate means and variation, lower temperature rises, and weaker periodicities. They also had higher coral cover and numbers of coral genera, and communities more typical of Indian Ocean coral communities undisturbed by temperature anomalies. Northwestern reefs had the lowest cumulative degree heating weeks and a high frequency of rare 'boutique' taxa that are usually found deeper or in lowdisturbance environments. Eastern reefs had a developed reef structure and may have the greatest potential for surviving climate change, while the northwest may be more amenable to protecting rare taxa. The more temperate reefs of the south showed large-scale degradation and no evidence for a refuge for coral communities, and require increased herbivory and associated fisheries management to reduce erect algal abundance.
\end{abstract}

KEY WORDS: Biodiversity $\cdot$ Climate change $\cdot$ Community structure $\cdot$ Insular ecology $\cdot$ Latitudinal range extension $\cdot$ Marine protected area planning $\cdot$ Oceanographic periodicity

\section{INTRODUCTION}

Islands create unique oceanographic conditions and variable physico-chemical environments that potentially influence ecological diversity (Kemp 1998, Schils \& Coppejans 2003, McClanahan et al. 2005). This is particularly true of large islands with environmental conditions that reflect both latitudinal and island effects (Lutjeharms 2006). Madagascar is such an example, as the island covers $14^{\circ}$ of latitude $\left(11^{\circ} 47^{\prime}\right.$ to $25^{\circ} 35^{\prime} \mathrm{S}$ ); it is a transition from tropical to subtropical and semi-temperate climatic conditions, and the East African Equatorial Current and the island interact to create distinct oceanographic environments that have been stable for the last $\sim 2$ million yr (Winter \& Martin 1990). Despite this stability, recent oceanographic anomalies associated with a warming climate (Jury et al. 1995, Reason \& Lutjeharms 1998, Fyfe 2006) may be influencing the spatial signature of El Niño Southern (ENSO) and Indian Ocean Dipole (IOD) oscillations (Zinke et al. 2004).

The diversity of oceanographic environments created by the island of Madagascar has the potential to illuminate the effects of climate change on insular coral reefs (McClanahan et al. 2005, 2007a, Maina et al. 2008). Additionally, a network of terrestrial and marine protected areas that considers the potential effects of climate change is being planned for Mada- 
gascar (Kremen et al. 2008). Consequently, in order to predict the performance of the planned marine protected areas with climate change, Madagascar's temperature histories over the past $55 \mathrm{yr}$ were evaluated in 3 oceanographic regions, namely the southwest, northwest, and east. These data were then compared with benthic cover and coral community structure data in order to improve understanding of the interactions between islands and oceanography, and associated temperature effects on coral reefs.

\section{Oceanography of Madagascar}

Madagascar's coastline contains diverse environments created by the interaction between the East African equatorial current system and the island. The eastern side of Madagascar has a narrow, more stable, and deeper thermocline than the western side (Lutjeharms 2006). The surface circulation on this windward side is wind-driven and impinges on this eastern side of the island at about $17^{\circ} \mathrm{S}$ and splits into northern and southern boundary currents (Swallow et al. 1988). When these currents reach the end of the island, they form complex gyres and eddies with localized upwelling and retention areas on both the northern and southern ends of the island (Saetre 1985, Machu et al. 2002, Quartly \& Srokosz 2004).

The narrowing in the Mozambique Channel creates large tidal ranges with means at spring tide of $3.8 \mathrm{~m}$ in the north and $2.6 \mathrm{~m}$ in the south while the eastern coast tides range from about $0.5 \mathrm{~m}$ in the southeast to $1.0 \mathrm{~m}$ in the east. Madagascar's largest rivers drain to the west and bring seasonal pulses of fresh water and sediment. The western side of Madagascar is subsiding faster than sea-level rise, and modern reefs on the southwestern side grow on top of subsided Pleistocene reefs (Camoin et al. 2004).

\section{Reef distribution and biodiversity}

The coral reefs of Madagascar have been studied taxonomically but information on environmental conditions, ecology, and country-scale biodiversity patterns is sparse (Gabrié et al. 2000, Cooke et al. 2003). Madagascar's coral reefs have an estimated total length of $3540 \mathrm{~km}$, of which the principal concentrations of emergent reefs are in the east (Cap d'Ambre to Toamasina, $417 \mathrm{~km}$ ), southwest (Androka to Morombe, $458 \mathrm{~km}$ ), and northwest (Mahajanga to Cap d'Ambre, $578 \mathrm{~km}$ ) (Gabrié et al. 2000). Prior to a recent expedition to northwestern Madagascar, the number of coral species was estimated at 60 genera and 208 species (Sheppard 1998). A more recent taxonomic survey and compilation of previous studies found 62 genera and 323 species in the northwest region alone, making the current total for Madagascar 380 species, which is the highest coral richness in the central and western Indian Ocean studies (Veron \& Turak 2005). Mollusk and fish studies have, however, found species richness more typical of other countries and sites in the region (McClanahan 2002, Allen 2005, Wells 2005).

Global climate change and anthropogenic impacts are having large effects on coral reef ecosystems. Coral reefs in particular have undergone significant degradation over the past few decades (Bruno \& Selig 2007). In the face of global and region-wide threats to coral populations and communities (Carpenter et al. 2008), questions arise about the environmental and ecological factors that will allow persistence of coral reef species and communities (Glynn 1996, West \& Salm 2003, McClanahan et al. 2007a, Maina et al. 2008). The variable oceanographic dynamics of Madagascar provide an opportunity to investigate the influence of local and regional climate-change hydrodynamics on coral reefs that should contextualize and provide scenarios for future climate-change effects.

\section{MATERIALS AND METHODS}

Study area and benthic sampling. We studied reefs in 3 regions of Madagascar known for their extensive reef structure and diversity of coral taxa: the eastern windward region of the Masoala Peninsula, the northwestern region around Nosy Be, and the southwestern region around Rano Be and Tulear (Fig. 1). The 6 sites in the Masoala area were in the closure, the buffer zone, and outside of the marine protected closures areas of Masola and Tanjona that were established in 1999 (Kremen et al. 1999, McClanahan 2007). The northwestern Nosy Be sites included 2 sites within a marine reserve, Nosy Tanikely, and 2 sites in unmanaged reefs on the shorelines or nearshore islands of Nosy Be, namely Sakatia and Ambaritelo. Nosy Tanikely was declared a marine reserve in 1968 (Arrêté 4730 Journal Officiel 2232, 30 November 1968). Four sites were studied in the Rano Be area: Beantsisy, False Pass, Rose Garden, and the South Pass off of Ifaty. Three back-reef lagoonal sites were sampled in the Grande Recife area of Tulear in southwestern Madagascar: Ankolaste, Ambato Be, and Besaraboka. A final site further south of Grande Recife included the coral cay of Nosy Ve Anakao where some coral community data were collected. All sites were sampled in 2007 and 2008.

Sea surface temperature (SST). Two SST data sets were analyzed. First, long-term in situ and remotely sensed Hadley Centre SST (HADISST) data were used 
Fig. 1. Study sites, regions where temperature data were analyzed, and the major coral reef areas. Numbered squares indicate the locations of the Hadley Centre sea surface temperature (HADISST) data locations

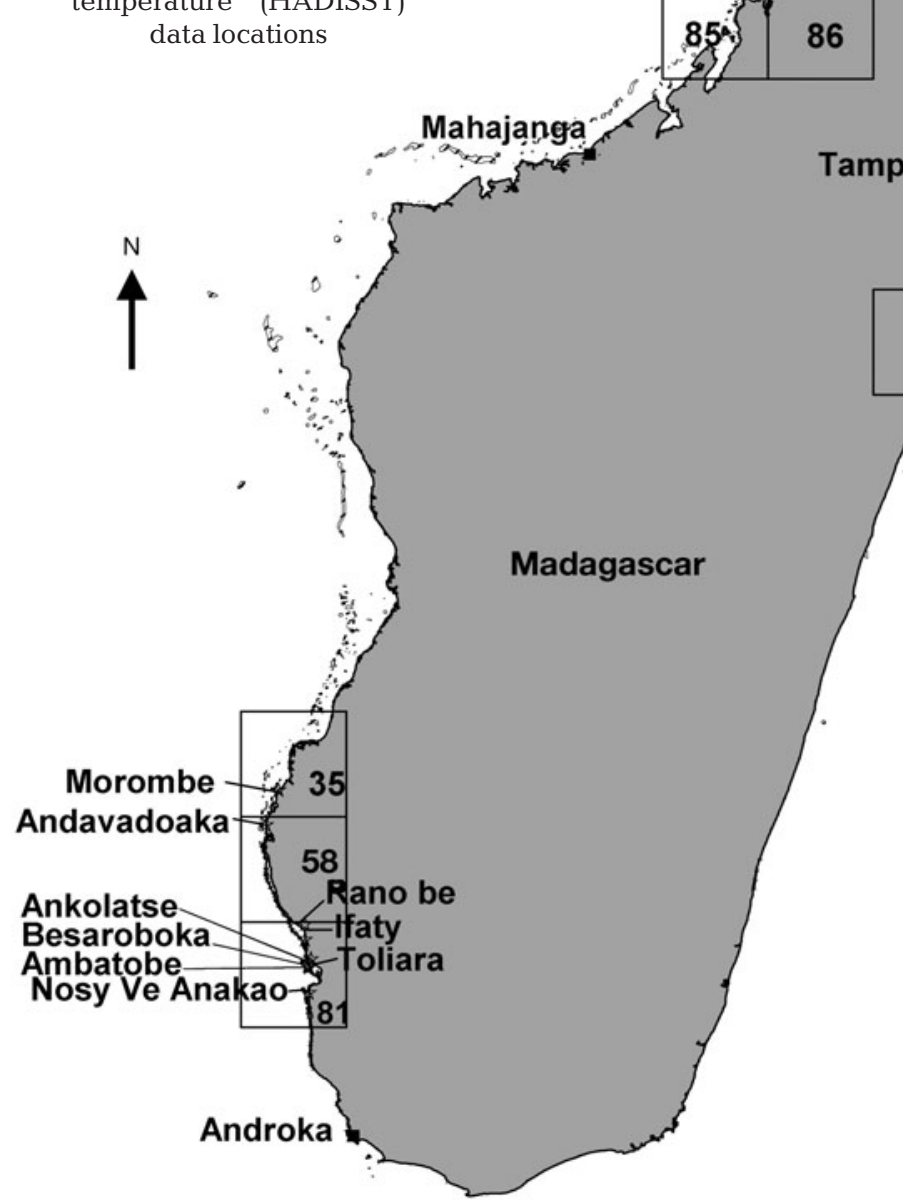

in order to determine the region-wide spatio-temporal variability (www.cru.uea.ac.uk; Rayner et al. 2003). The HADISST data provided continuous monthly means in $1^{\circ} \times 1^{\circ}$ longitude-latitude, and we analyzed the 1951 to 2005 monthly time series. The HADISST has high accuracy but low spatial resolution (Rayner et al. 2003). For this reason, we also obtained highresolution $(4 \mathrm{~km} \times 4 \mathrm{~km})$ NOAA SST data (1981 to 2006) and calculated a similar set of SST statistics (www.osdpd.noaa.gov). For each square, we also obtained the degree heating weeks (DHW; $50 \times 50 \mathrm{~km}$ resolution) for 1998, 2001, 2002 to 2004, and 2006 when bleaching was reported in the region. DHW is the number of weeks when the temperature is $>1^{\circ} \mathrm{C}$ above the long-term average of the 3 warmest mo based on the full time series (maximum summer climatology; Liu et al. 2006). In addition, we calculated the cumulative DHW by summing the DHWs for all $6 \mathrm{yr}$.
Similarly, degree heating months (DHM), the number of months with $>1{ }^{\circ} \mathrm{C}$ above the long-term average, was determined for 1998, a strong ENSO-IOD year, using the HADISST data.

Based on maps of the distribution of coral reefs in Madagascar (Spalding et al. 2001), we analyzed temperature data in 3 regions, east, northwest, and southwest, that contained the most reef area (Fig. 1). Each of the regions covered approximately 200 to $500 \mathrm{~km}^{2}$ reef areas. In each region, 2 to 5 of the largest reefs were chosen for a corresponding analysis of the temperature data, and the temperature cells that overlay the main large reefs on the map in each geographic region were used in the analyses. To describe the temporal fluctuations, annual means, standard deviations (SDs), kurtosis, and skewness of SSTs were calculated for each area using the 2 data sets.

Benthic and coral field studies. Two field sampling methods were undertaken, one using standard line or point-intercept transects (McClanahan \& Shafir 1990) to describe the main benthic functional groups, and the second using a haphazard-swim procedure to describe just the hard coral community (McClanahan et al. 2007a). The intercept method is based on 9 haphazardly placed draped $10 \mathrm{~m}$ transects where all organisms $>3 \mathrm{~cm}$ were classified into 6 gross functional groups (turf, calcareous, erect fleshy and encrusting coralline algae, hard coral, other invertebrates) and sand. Percentage cover was calculated based on the sum of each category divided by the combined measurements.

The haphazard swim included observations made in shallow $(<3 \mathrm{~m})$ field sites while snorkeling for a $\sim 40$ min period. Observers swam with eyes closed in haphazardly chosen directions and distances and periodically or haphazardly opened their eyes and sampled the areas directly beneath themselves. All hard coral colonies within $\sim 2 \mathrm{~m}$ radius beneath the observer were identified to genus and counted.

Statistical analyses. Water temperature and benthiccover data were tested for significance between regions using 1-way ANOVA and post hoc comparisons. Prior to these tests, Levene's test of homogeneity of variance was used to check the assumptions of parametric statistics. When different common transformations did not achieve normalization, untransformed data were used and significance was checked with a nonparametric Wilcoxon or Kruskal-Wallis rank-sum tests. Simple linear regression analyses were used to 
compare the interrelationships between the different temperature statistics of mean, SD, annual rate of rise, and DHM in 1998 (DHM98) and summed across the 1998 to 2006 period. Time series analysis of the SST monthly means was conducted to determine the strength of inter-annual periodic events including ENSO and IOD years (Saji et al. 1999). In addition, the relationship of the cumulative DHW with the different SST properties was analyzed using stepwise multiple regression analyses for the NOAA SST data.

Comparisons of benthic-cover categories were made after a test of normality of the data and based on these results, either the Kruskal-Wallis tests or 1-way ANOVA were completed and followed by a post hoc comparison of the means for each region. Relative abundance of the different coral taxa was used in multivariate detrended correspondence analysis (DCA) to distinguish the communities' associations among the reefs. Cumulative numbers of taxa (genera and 2 growth forms of the genera Porites and Galaxea) against the number of individuals was calculated as our estimate of taxonomic richness, where data were pooled into the 3 regions for comparisons. All analyses were done using JMP statistical software (Sall et al. 2001). To test if the regional variation in coral cover was related to SST patterns of stress, we conducted a linear regression analysis between coral cover, community composition based on the DCA, and the recent cumulative DHW (1998 to 2006).

\section{RESULTS}

\section{Water temperature}

The mean, minimum, maximum, SD, kurtosis, and skewness of the HADISST data were different between the 3 regions (Table 1). Patterns in NOAA SST data were in approximate agreement with those of HADISST, although NOAA SST data had higher variation than HADISST data. NOAA data had slightly higher SSTs in the northwest than the HADISST data. There were no differences in skewness among regions in the NOAA SST data, and skewness data were slightly positive in the NOAA and negative in the HADISST data. DHM and DHW values for 1998 were in disagreement in the 2 data sets: HADISST indicated 8 to 10.5 whereas the NOAA data indicated 1.7 to 6.7 DHW. There were small differences between sites for the HADISST data, while NOAA SST data showed the highest DHW98 for the east and lowest for the northwest.

The southwest region was the coolest and had the most variability, including the lowest minimum and maximum SSTs and the fastest annual rate of rise. The warmest temperatures were recorded in the northwest, including high minimum temperatures, but low SDs. The eastern region had the lowest mean HADISST temperatures but NOAA SST data indicated equally low values for the east and southwest. The southwestern region had the highest SST SD and annual rate of rise; the northwest and eastern regions had annual temperature rises one-third slower than the southwest region. The overall cumulative DHWs for the recent warm years (1998, 2001 to 2006) were different for all regions, with high values in the southwest and lowest in the northwest.

Time series analysis of the longer HADISST indicated an overall SST rise, and some shared peak high temperatures in 1960, 1983, and 1998 (Fig. 2a). In all sites except the southwest, the SST SDs cycled with high variation in the 1950s and 1960s and again after the 1990s, but with low variation during the 1970s and 1980s (Fig. 2b). Overall SST kurtosis decreased after

Table 1. Comparison of differences among sea surface temperature (SST) variables between studied regions based on monthly replicated $100 \times 100 \mathrm{~km}$ Hadley Centre SST (HADISST) data for the years between 1951 and 2005, and 1981 to 2006 NOAA SST $(4 \times 4 \mathrm{~km})$ data. DHM98: degree heating months in 1998; DHW: degree heating weeks; DHW98: DHW in 1998; na: ANOVA was not computed due to lack of sufficient replication

\begin{tabular}{|c|c|c|c|c|c|c|c|c|c|c|}
\hline \multirow{3}{*}{ Variable } & \multirow{2}{*}{\multicolumn{3}{|c|}{$\begin{array}{c}- \text { HADISST data } \\
\text { Reef region }\end{array}$}} & \multirow{2}{*}{\multicolumn{2}{|c|}{ ANOVA }} & \multirow{2}{*}{\multicolumn{3}{|c|}{$\begin{array}{l}- \text { NOAA SST dat } \\
\text { Reef region }\end{array}$}} & \multirow{2}{*}{\multicolumn{2}{|c|}{ ANOVA }} \\
\hline & & & & & & & & & & \\
\hline & $\begin{array}{l}\text { East } \\
(\mathrm{n}=4)\end{array}$ & $\begin{array}{l}\text { Northwest } \\
(\mathrm{n}=5)\end{array}$ & $\begin{array}{l}\text { Southwest } \\
(\mathrm{n}=3)\end{array}$ & F & $\mathrm{p}$ & $\begin{array}{l}\text { East } \\
(\mathrm{n}=8)\end{array}$ & $\begin{array}{l}\text { Northwest } \\
(\mathrm{n}=4)\end{array}$ & $\begin{array}{l}\text { Southwest } \\
(\mathrm{n}=7)\end{array}$ & $F$ & $\mathrm{p}$ \\
\hline Mean SST $\left({ }^{\circ} \mathrm{C}\right)$ & $26.56^{b}$ & $27.17^{\mathrm{a}}$ & $26.18^{\mathrm{c}}$ & 149.3 & $<0.0001$ & $26.49^{a}$ & $28.05^{\mathrm{b}}$ & $26.45^{\mathrm{a}}$ & 2175.12 & $<0.0001$ \\
\hline Minimum SST $\left({ }^{\circ} \mathrm{C}\right)$ & $24.14^{\mathrm{b}}$ & $24.78^{a}$ & $23.48^{\mathrm{c}}$ & 158.2 & $<0.0001$ & $24.31^{\mathrm{a}}$ & $25.94^{\mathrm{b}}$ & $23.42^{\mathrm{c}}$ & 164.57 & $<0.0001$ \\
\hline Maximum SST $\left({ }^{\circ} \mathrm{C}\right)$ & $28.67^{\mathrm{b}}$ & $29.14^{\mathrm{a}}$ & $28.7^{\mathrm{b}}$ & 20.6 & $<0.0001$ & $29.6^{\mathrm{a}}$ & $30.5^{\mathrm{b}}$ & $29.98^{\mathrm{c}}$ & 60.33 & $<0.0001$ \\
\hline $\operatorname{SD}$ of $\operatorname{SST}\left({ }^{\circ} \mathrm{C}\right)$ & $1.58^{\mathrm{b}}$ & $1.43^{\mathrm{c}}$ & $1.79^{a}$ & 102.1 & $<0.0001$ & $1.9^{\mathrm{a}}$ & $1.51^{\mathrm{b}}$ & $2.08^{\mathrm{c}}$ & 140.9 & $<0.0001$ \\
\hline Kurtosis of SST & $-1.54^{\mathrm{b}}$ & $-1.48^{\mathrm{a}}$ & $-1.51^{\mathrm{a}, \mathrm{b}}$ & 5.2 & $<0.001$ & & & & & \\
\hline Skewness of SST & $-0.18^{\mathrm{b}}$ & $-0.27^{\mathrm{c}}$ & $-0.05^{\mathrm{a}}$ & 62.5 & $<0.0001$ & 0.12 & 0.01 & 0.07 & 1.36 & 0.29 \\
\hline SST rise $\left({ }^{\circ} \mathrm{C} \mathrm{yr}^{-1}\right)$ & 0.0051 & 0.0066 & 0.0175 & na & na & na & na & na & & \\
\hline DHM98 & 2.25 & 2.66 & 1.94 & na & na & na & na & na & & \\
\hline DHW98 & & & & & & $6.74^{\mathrm{a}}$ & $1.71^{\mathrm{b}}$ & $4.06^{\mathrm{c}}$ & 86.22 & $<0.0001$ \\
\hline Recent cumulative DHV & & & & & & $8.26^{\mathrm{a}}$ & $3.18^{\mathrm{b}}$ & $16.51^{\mathrm{c}}$ & 198.21 & $<0.0001$ \\
\hline
\end{tabular}



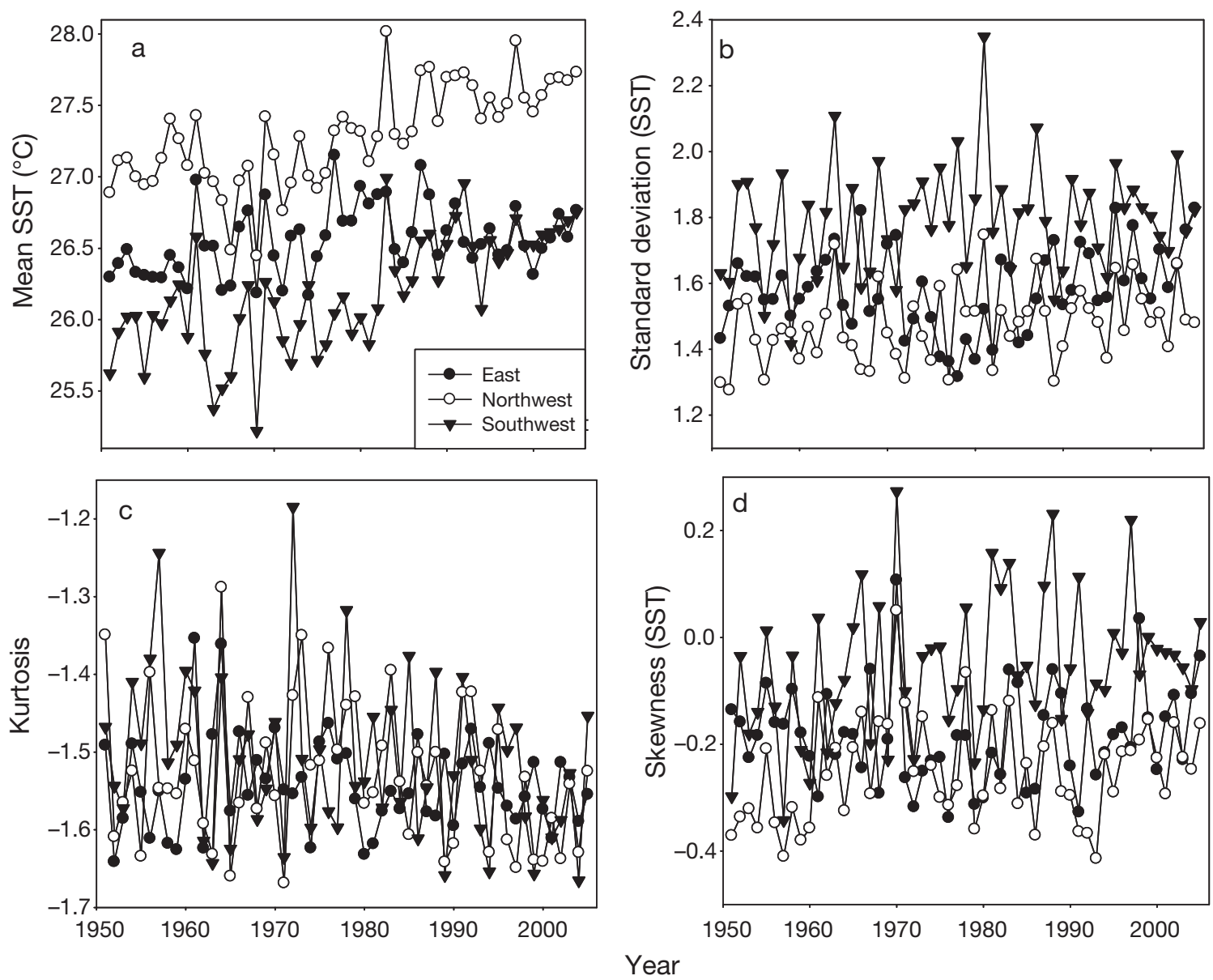

Fig. 2. Time series of (a) annual mean sea surface temperature (SST), (b) SDs, (c) kurtosis, and (d) skewness of Hadley Centre SST (HADISST) for the 3 studied regions in Madagascar. Data are from replicate $1^{\circ} \times 1^{\circ}$ longitude-latitude squares pooled into 3 areas, east, northwest, and southwest

the 1970 s accompanied by reduction in variability especially in the southwestern region (Fig. 2c). The SST skewness increased continously (Fig. 2d) with highest values in the southwestern region.

As for relationships between temperature variables, except for skewness, most of the SST variables were significantly correlated (from $\mathrm{r}=0.52$ for maximum-SD SST to $r=-0.96$ for minimum-SD SST). Temperature variation (SD) declined with increasing mean temperature, with the HADISST data having lower variation for the same temperatures than the NOAA SST data (Fig. 3a). The DHM98 and temperature variation relationships were complex because of the very different predictions for the northwest region by the 2 data sources. The NOAA DHW98 for the 5 recent warm years increased with SST variation, which was the opposite of the negative relationship for the HADISST data (Fig. 3b). DHM98 was not linearly related to the annual rate of SST rise but highest in the east in the HADISST data and more variable when comparing the 2 data sources (Fig. 3c). Patterns in NOAA DHW98 were mainly explained by the maximum value and skewness of the SST. The cumulative DHW for 1998 to 2006 was positively associated with the variation and the maximum value of the SST and weakly negative with skewness of the SST (Fig. 3d, Table 2). High SST variation sites in the southwest had the highest cumulative DHW, which were largely attributed to high values after 1998.

Table 2. Results of stepwise multiple regression analysis on the effects of NOAA sea surface temperature (SST) properties on the level of heating (degree heating weeks [DHW]) in 1998

$(\mathrm{DHW} 98 ; \mathrm{df}=16)$ and over the 1998 to 2006 period $(\mathrm{df}=15)$

\begin{tabular}{|lccc|}
\hline Parameter & $F$ & $\mathrm{p}$ & Relationship \\
\hline DHW98 & & & \\
Maximum SST & 102.41 & $<0.0001$ & Negative \\
Skewness of SST & 33.8 & $<0.0001$ & Positive \\
DHW (1998-2006) & & & \\
SD of SST & 224.68 & $<0.0001$ & Positive \\
Maximum SST & 26.34 & 0.0001 & Positive \\
Skewness of SST & 4.97 & 0.04 & Negative \\
\hline
\end{tabular}



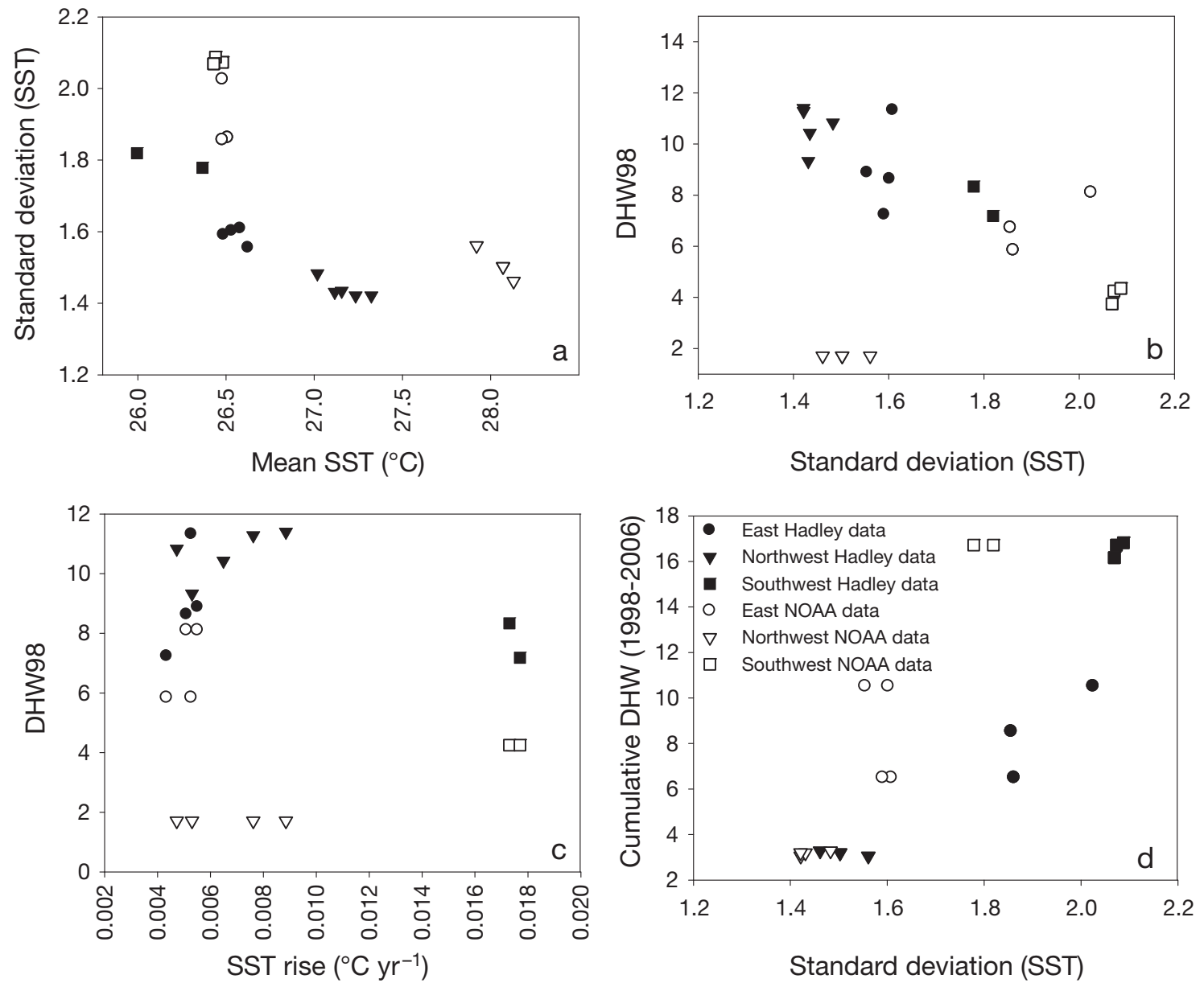

Fig. 3. Interrelationships between the key summary temperature statistics for each region across the entire time series. (a) Mean sea surface temperature (SST) and SD, (b) degree heating months in 1998 (DHM98) and SD, (c) rate of SST rise and DHM98, and

(d) cumulative degree heating weeks (DHW) for 1998 to 2006 and SD for the 2 temperature data sets

SST intra-annual variation was higher in winters than summers in the east and northwest but more similar and with high variation in the southwest (Table 1). SST inter-annual periodicities based on the longer HADISST data were most commonly observed at around 50 to 60 mo and the strongest SST periodicities were in the southwest with strong cycles at $\sim 50,130$, and 160 mo (Fig. 4). Periodicities in the northwest and east were considerably weaker than in the southwest.

\section{Benthic communities}

All benthic-cover variables with the exception of sand were different for comparisons between regions (Table 3). Hard-coral cover was around $30 \%$ of the cover and not different between the east and northwest, but both of these were higher than in the southwest region. Erect fleshy algal

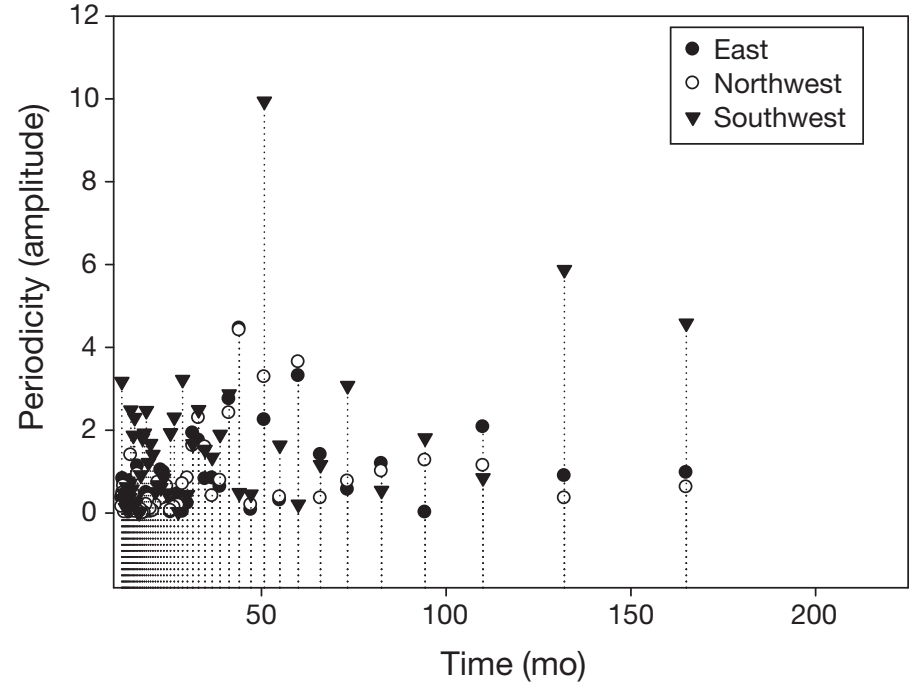

Fig. 4. Periodicity of recurring patterns in sea surface temperature (SST) displayed in each area throughout the $54 \mathrm{yr}$ time period in the 3 coral reef regions. Periodicity of patterns $<12$ mo were removed to focus on inter-annual periodicities 
Table 3. Comparison of percent cover of the benthic/substrate categories from line-intercept transects in the studied reef regions. Cover on the east is based on 6 sites, northwest on 4 sites, and southwest on 7 sites. ns: not significant; SEM: standard error of the mean

\begin{tabular}{|c|c|c|c|c|c|c|c|c|}
\hline \multirow{2}{*}{ Substrate group } & \multicolumn{2}{|c|}{ East } & \multicolumn{2}{|c|}{ Northwest } & \multicolumn{2}{|c|}{ Southwest } & \multicolumn{2}{|c|}{ Statistical comparison } \\
\hline & Mean & SEM & Mean & SEM & Mean & SEM & $F: \chi$ ratio & $\mathrm{p}$ \\
\hline Hard coral & $27.84^{\mathrm{a}}$ & 1.78 & $34.47^{\mathrm{a}}$ & 9.09 & $11.98^{\mathrm{b}}$ & 4.89 & 10.14 & $<0.001$ \\
\hline Algal turf & $38.90^{\mathrm{a}}$ & 3.67 & $32.21^{\mathrm{a}, \mathrm{b}}$ & 9.70 & $20.25^{\mathrm{b}}$ & 5.45 & 7.58 & $<0.01$ \\
\hline Calcareous algae* & $13.85^{\mathrm{a}}$ & 3.26 & $2.74^{\mathrm{b}}$ & 3.16 & $0.71^{\mathrm{b}}$ & 0.49 & 15.59 & $<0.001$ \\
\hline Fleshy algae* ${ }^{*}$ & $5.48^{\mathrm{b}}$ & 0.95 & $2.99^{b}$ & 3.32 & $41.90^{\mathrm{a}}$ & 8.86 & 17.44 & $<0.001$ \\
\hline Coralline algae & $2.00^{\mathrm{c}}$ & 1.80 & $11.74^{\mathrm{a}}$ & 3.16 & $19.20^{\mathrm{b}}$ & 2.19 & 20.83 & $<0.0001$ \\
\hline Sand $^{*}$ & 7.46 & 1.59 & 3.39 & 1.15 & 5.42 & 2.89 & 3.53 & $\mathrm{~ns}$ \\
\hline Soft coral + sponge ${ }^{*}$ & $5.25^{\mathrm{a}, \mathrm{b}}$ & 1.90 & $12.37^{\mathrm{a}}$ & 7.30 & $0.42^{\mathrm{b}}$ & 0.17 & 19.57 & $<0.0001$ \\
\hline
\end{tabular}

cover displayed the opposite pattern, with very high cover in the southwest (42\%) and similarly low cover in the east and northwest (3\%). Calcareous green algae cover was highest in the east and coralline algae cover highest in the west. Soft coral and sponge had higher cover in north and were uncommon in the southwest.

The first 3 axes of the DCA explained $57 \%$ of the variation in the hard-coral community based on data collected by the haphazard-swim method (Fig. 5). Southwest sites were most different, with Rose Garden and Beantsisy distinguished by high dominance of the genera Montipora and Oulophyllia and False Pass and South Pass by Seriatopora and Pocillopora (Fig. 5a). Alveopora, Cyphastrea, Echinophyllia, Montastrea, massive Porites, Pavona, Pocillopora, and Stylophora also distinguished southwest sites in Grande Recife. After removing southwest sites, the northeast sites of Nosy Be sites were differentiated by 'boutique' taxa such as Diploastrea, Herpolitha, Halomitra, Mycedium, and Synarea distinguishing some of the Tanikely and Ambaritelo sites (Fig. 5b). Acanthastrea, Astreopora, Gardinoseris, Montastrea, Oxypora, Symphyllia, and Physogyra distinguished Sakatia and 1 site at Tanikely. Eastern sites were more uniform and had common dominants in the Western Indian Ocean region (WIO) region, including Acropora, Millepora, Pocillopora, Porites, and the common faviids (Fig. 6). New taxa were encountered at the highest rates in the northwest region of Nosy Be and a total of 41 taxa were found in both the northwest and east sites for 3140 and 5880 individuals sampled, respectively. The lowest cumulative taxa were found in the southwest, with 35 taxa for 3202 sampled individuals.

Regional variation in coral cover declined significantly with the cumulative DHW (Fig. $7 \mathrm{a} ; \mathrm{R}^{2}=0.39$; $F=10.73 ; \mathrm{p}=0.005)$. Stepwise multiple regression analysis showed significant relationships between SST properties and the DCA loadings for the coral community structure (Table 4). The mean, variation, and max- imum SST explained most of the variation in the first DCA (53\%) while the minimum and maximum SST explained variations in the 2nd DCA axis (69\%). The 2nd axis also had a significant relationship with the cumulative DHW for 1998 to 2006 (Fig. $7 b ; R^{2}=0.62$; $F=23.17 ; \mathrm{p}=0.0003)$ while the 1 st axis did not $(\mathrm{p}=$ 0.39). Alveopora, Coscinarea, Montipora, Oulophyllia, and Stylophora in the southwest are the taxa largely responsible for this relationship. None of the DCA axes had significant relationships with the DHW in 1998 ( $\mathrm{p}>0.05)$.

\section{DISCUSSION}

Madagascan reefs exist in variable oceanographic and temperature environments, all of which are showing evidence of a warming SST, albeit at different rates and within the context of different intra- and interannual SST cycles. The southern leeward side of Madagascar is experiencing the fastest temperature rise at $\sim 0.016^{\circ} \mathrm{C} \mathrm{yr}^{-1}$, which is about 3 times faster than the

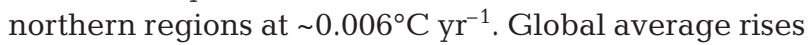
over this period and in East Africa (Kenya, Tanzania, and northern Mozambique) are $\sim 0.010^{\circ} \mathrm{C} \mathrm{yr}^{-1}$ (McClanahan et al. 2007b), and therefore the southwest region is above and northern regions below this mean rate. The southwest region is also characterized by large inter- and intra-annual variability that is persistent through winter and summer seasons and experiencing strong periodicities at different frequencies. The 50 to 60 yr cycle has been found in many temperature time series for the region and is probably a combination of the IOD and ENSO cycles (Saji et al. 1999, Cole et al. 2000, Kayanne et al. 2006, Sakova et al. 2006). The strong temperature rise in 1961 is most likely an IOD effect, whereas the 1983 event is a strong ENSO effect, and the 1998 peak reflects a combined ENSO and IOD interaction (Saji et al. 1999). 


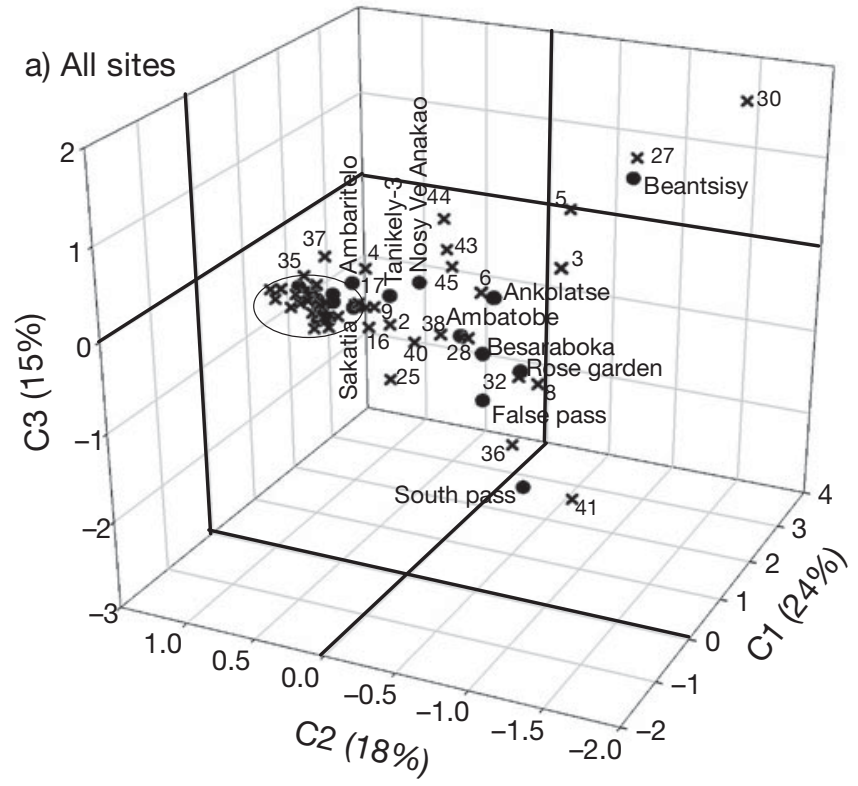

b) Northwestern and Eastern sites

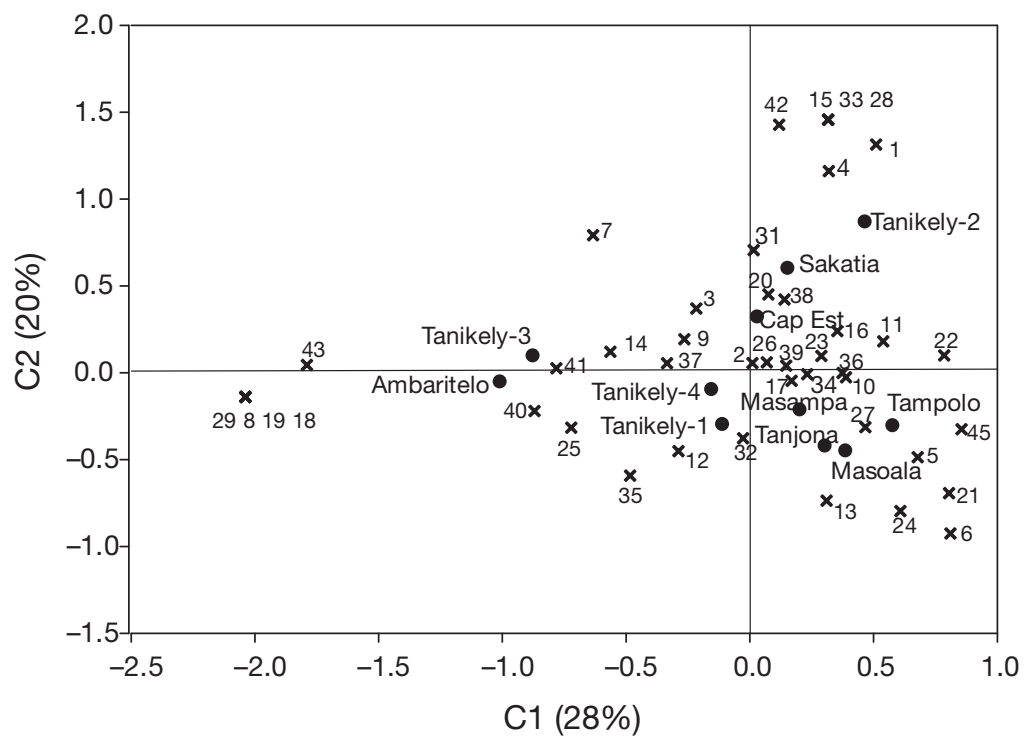

Fig. 5. Multivariate detrended correspondence analysis (DCA) plot of the relationships in coral community structure (a) among all the studied reef sites and (b) among the Northern reef sites; $\bullet$, reef sites and $\mathbf{X}$, coral genera labeled 1: Acanthastrea, 2: Acropora, 3: Alveopora, 4: Astreopora, 5: Coscinaraea, 6: Cyphastrea, 7: Diploastrea, 8: Echinophyllia, 9: Echinopora, 10: Favia, 11: Favites, 12: Fungia, 13; Galaxea astreata, 14: Galaxea fascicularis, 15: Gardinoseris, 16: Goniastrea, 17: Goniopora, 18: Halomitra, 19: Herpolitha, 20: Hydnophora, 21: Leptastrea, 22: Leptoria, 23: Lobophora, 24: Lobopyllia, 25: Merulina, 26: Millepora, 27: Montipora, 28: Montastrea, 29: Mycedium, 30: Oulophyllia, 31: Oxypora, 32: Pavona, 33: Physogyra, 34: Platygyra, 35: Plerogyra, 36: Pocillopora, 37: Porites branching, 38: Porites massive, 39: Psammocora, 40: Seriatopora, 41: Stylophora, 42: Symphyllia, 43: Synarea, 44: Tubastrea, 45: Turbinaria. Overlapping coral genera: 1, $2,4-6,9-13,15-17,20-24,26,28,29,31-34,36,39,41,42$, and 45. Overlapping sites are Cap Est, False Pass, Masampa, Masoala, Sakatia, Tanikely-1, Tanikely-2, Tanjona, and Tampolo
When the Southern Oscillation Index (SOI) is weak, there is a strong correlation with the Pacific ENSO in southwest Madagascar, based on a 336 yr temperature record from Ifaty (Zinke et al. 2004). During the period from 1960 to the time when the core was collected in 1995, temperature cycles were strongly correlated with ENSO-like periodicity. The investigation found the warmest period to be between 1980 and 1995, which was preceded by a cool period from 1970 to 1980 (Zinke et al. 2004). Compared with the data in the present study, the cool period is associated with the lower SST SDs in all regions except in the southwest. In contrast, there was reduced SST variation in the southwest during the past few decades, different from the other regions, and this may be associated with a weakening of the shallow water overturning in the southern Indian Ocean between 1992 and 2000 (Lee 2004).

Regional-level oceanographic variation is expected to influence responses to climate change (McClanahan \& Maina 2003, McClanahan et al. 2007b, Maina et al. 2008). Coral vulnerability to temperature thresholds and anomalies is complex, where all of the factors of temperature (means and maxima, variations, rate of rise), UV light, wind, and currents interact to influence responses (Coles \& Brown 2003, Maina et al. 2008). The rate at which temperatures approach the thresholds for coral survival has been used to predict the future mortality or ecological extinction of corals (Hoegh-Guldberg 1999, Hughes et al. 2003, Sheppard 2003). Thresholds and their plasticity will also be influenced by the interaction between background temperature variation and the strength of the periodicities and anomalies and coral acclimatization and adaptation (Hughes et al. 2003, Sheppard 2003, McClanahan et al. 2005, 2007b, Baskett et al. 2009). Despite these predictions, a negative relationship was found between SST rise and the intensity of bleaching in a study compiling bleaching records for the whole tropical western Indian Ocean (Maina et al. 2008).

In a spatially limited study of the tropical East African coastline $(\sim 1000 \mathrm{~km})$, McClanahan et al. (2007b) found that the 


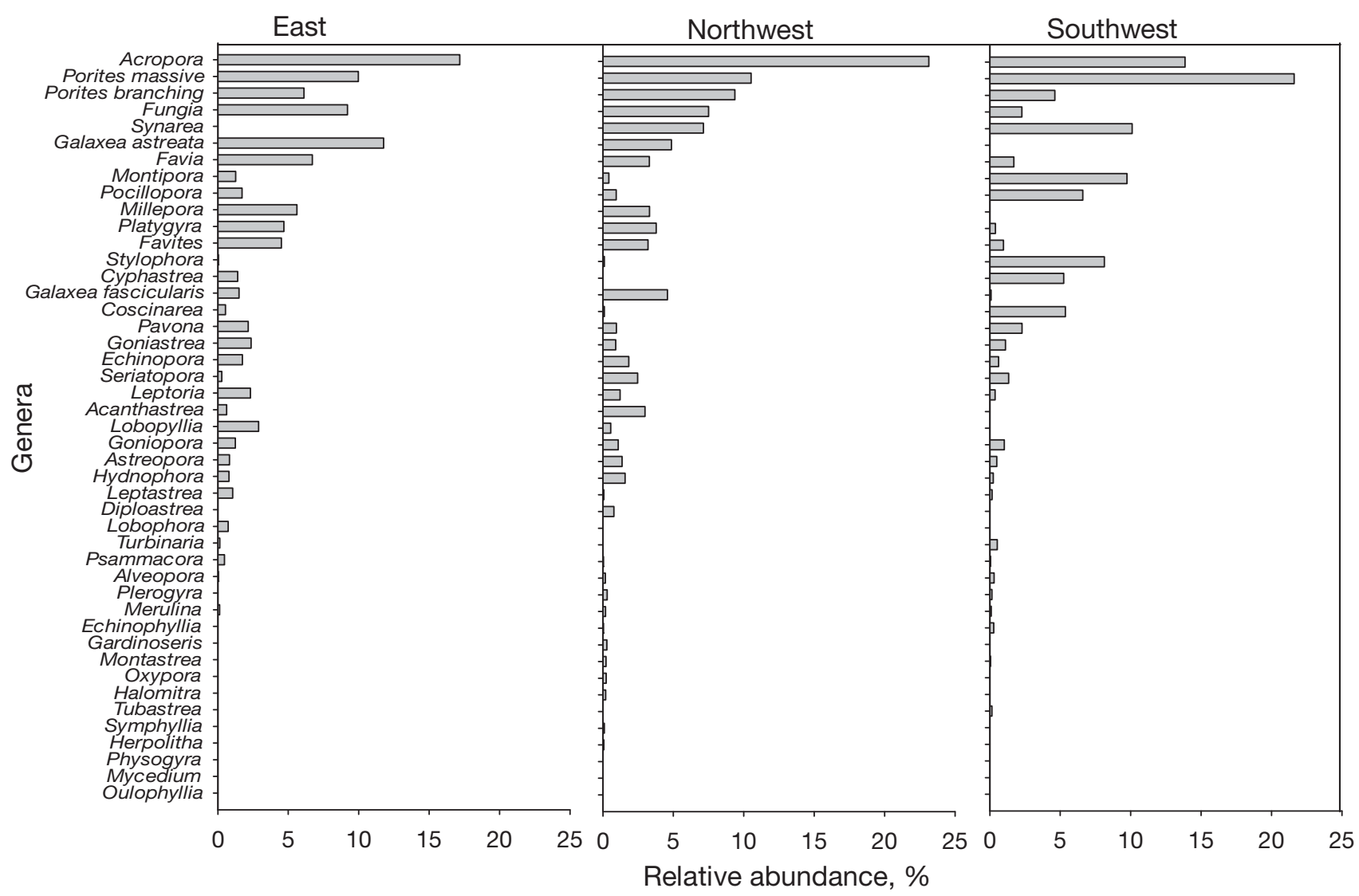

Fig. 6. Relative abundance of coral genera in the 3 studied regions. Genera are ranked from the most to the least dominant, based on total abundance from all sites

level of anomalous heating during the strong 1998 ENSO-IOD event did not show a relationship with the rate of temperature rise. Reefs with intermediate levels of SST rise had the highest anomalous heating and expected coral bleaching and mortality. Along the African coastline, the DHWs in 1998 were strongly negatively associated with temperature variation. DHW and coral mortality levels decreased with an increase in temperature variation. In the present study, we observed the opposite, with high cumulative DHW in the southwest associated with high temperature variation and low hard coral and high erect algal cover. Most of the cumulative DHW in the southwest occurred after 1998. These conflicting observations are not easily explained, but suggest some non-linear or threshold relationships associated with latitude and regional oceanography that may have important consequences for coral survival.

Moderate SST SD of $~ 1.5$ may give northwestern and eastern Madagascar corals some acclimatization or adaptation potential (McClanahan et al. 2007b), but the potential effect of climate change on these reefs requires more study of their response and recovery from temperature anomalies. The interaction between low temperature rises, weak rare periodicities, and moderate SST SDs may provide these reefs with some resistance to climate change. The northwest region could reach the hypothesized threshold for coral mortality sooner and have somewhat less acclimatization/ adaptation potential than eastern reefs due to their higher mean temperatures and lower SST SDs. Consequently, based on these criteria and a multivariate analysis of these and other factors (Maina et al. 2008), eastern reefs would appear to have the greatest potential for persistence through current climate warming and associated strong periodicities.

Southwest reefs have the most unusual temperature environment, being subtropical to temperate and strongly influenced by the southern gyre (Lutjeharms 2006). The low mean temperatures would suggest a delay in reaching lethal thresholds and a good prognosis across strong anomalies; however, the strong cumulative DHW, the fast SST rise, and strong and rare periodicities suggest otherwise. High SST variation may produce acclimatization/adaptation, but areas of very large variations of SD > 2.0 may be more susceptible 

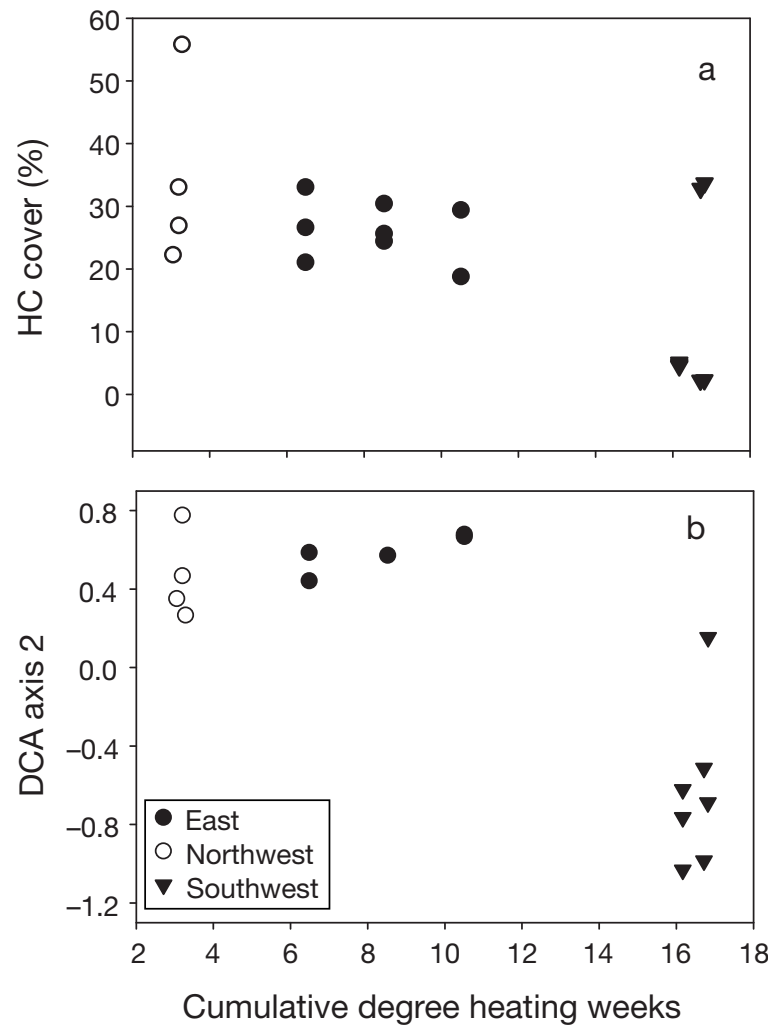

(1998-2006)

Fig. 7. Relationships between (a) HC (hard coral) cover and (b) community structure with NOAA cumulative degree heating weeks (DHW). Community structure is represented by the 2nd detrended correspondence analysis (DCA) axis, while DHW is cumulative for the recent warmer years (1998 to 2006)

Table 4. Results of stepwise multiple regression analysis on the relationship between sea surface temperature (SST) properties and the $1 \mathrm{st}(\mathrm{df}=12)$ and $2 \mathrm{nd}(\mathrm{df}=13)$ detrended correspondence analysis (DCA) axes of the coral community structure

\begin{tabular}{|lccc|}
\hline Parameter & $F$ & $\mathrm{p}$ & Relationship \\
\hline First DCA axis & & & \\
Mean SST & 12.52 & 0.004 & Positive \\
SD of SST & 12.87 & 0.004 & Positive \\
Maximum SST & 11.62 & 0.005 & Negative \\
Second DCA axis & & & \\
Minimum SST & 28.71 & 0.0001 & Positive \\
Maximum SST & 12.35 & 0.005 & Negative \\
\hline
\end{tabular}

to warming (Ateweberhan \& McClanahan unpubl.). Furthermore, the variation declined in the past few decades and may have made these reefs more vulnerable to strong anomalies since 2000. Southwest reefs were among the most degraded reefs studied, as indicated by their low numbers of coral taxa and dominance of erect algae, and are probably among the most degraded reefs in the western Indian Ocean (McClanahan et al. 2007a). Nevertheless, these reefs also experience heavy fishing and seasonally high river runoff and sediment inputs (Jaubert \& Vasseur 1974, Laroche \& Ramananarivo 1995). A combination of these factors is expected to contribute to their poor ecological state.

There were few quantitative data for Madagascar before the present study, in particular for the southwest region, although some reports (Ahamada et al. 2008) indicate strong bleaching events in 2001 and 2002 as indicated by the high DHW values and low coral cover. The high variation in coral cover in the southwest is due to the patchy distribution of the genus Montipora that was captured in some transects on the lagoonal reefs of Beantsisy and Rose Garden. The presence of high erect fleshy algal cover on southwest Madagascar reefs may not be new (Jaubert \& Vasseur 1974, Pichon 1978) but the shift from hard coral to erect algae dominance may have intensified after 1998, and may be responsible for the current poor state (Ahamada et al. in press, R. Stein-Rostaing pers. obs.). Regardless of the causes - climate anomalies, human resource use, eutrophication, or their interaction(s) this is a temperate reef environment that is unlikely to provide refuge for significant coral diversity during the expected period of climate warming (Precht \& Aronson 2004, Greenstein \& Pandolfi 2008).

Acknowledgements. Western Indian Ocean Marine Science Association Marine Science for Management Program, CARE-Masoala, the MacArthur Foundation, and the Wildlife Conservation Society financially support this research. ANGAP provided research clearance. For assistance with logistics, we thank A. Cooke, H. Crowley, J. Sebastien, R. Stein-Rostaing, and H. Randriamahazo. For assistance with fieldwork, we thank J. Sebastian, B. Remy-Zephir, and Jomanana. We thank the UK Met Office Hadley Centre for use of their global sea ice and SST data (HadISST1.1) set and are grateful to A. Edwards for assistance with extracting the data for this area.

\section{LITERATURE CITED}

Ahamada S, Bijoux J, Cauvin B, Harris A and others (2008) Status of the coral reefs of the south west Indian Ocean Island states: Comoros, Madagscar, Mauritius, Reunion, Seychelles. In: Wilkinson C (ed) Status of the coral reefs of the world 2008. Australian Institute of Marine Science, Townville, p 105-118

Allen GR (2005) Reef fishes of northwest Madagascar. In: McKeena SA, Allen GR (eds) A rapid biodiversity assessment of the coral reefs of northwest Madagascar. Conservation International, Washington, DC, p 39-48

Baskett M, Gaines SD, Nisbet RM (2009) Symbiont diversity may help coral reefs survive moderate climate change. Ecol Appl 19:3-17

Bruno JF, Selig ER (2007) Regional decline of coral cover in the Indo-Pacific: timing, extent, and subregional com- 
parisons. PLoS ONE 2:e711 doi:10.1371/journal.pone. 0000711

Camoin GF, Montaggioni LF, Braithwaite CJR (2004) Late glacial to post glacial sea levels in the western Indian Ocean. Mar Geol 206:119-146

Carpenter KE, Abrar M, Aeby G, Aronson RB and others (2008) One-third of reef-building corals face elevated extinction risk from climate change and local impacts. Science 321:560-563

Cole J, Dunbar R, McClanahan T, Muthiga N (2000) Tropical Pacific forcing of decadal SST variability in the western Indian Ocean over the past two centuries. Science 287: $617-619$

> Coles SL, Brown BE (2003) Coral bleaching - capacity for acclimatization and adaptation. Adv Mar Biol 46:183-223

Cooke AJ, Lutjeharms J, Vasseur P (2003) Marine and coastal ecosystems of Madagascar. In: Goodman S, Benstead J (eds) Natural history of Madagascar. Chicago University Press, Chicago, IL, p 179-208

Fyfe JC (2006) Southern Ocean warming due to human influence. Geophys Res Lett 33:L19701 doi:10.1029/ 2006GL027247

Gabrié C, Vasseur P, Randriamiarana H, Maharavo J, Mara E (2000) The coral reefs of Madagascar. In: McClanahan TR, Sheppard CRC, Obura DO (eds) Coral reefs of the Indian Ocean: their ecology and conservation. Oxford University Press, New York, NY, p 411-444

Glynn PW (1996) Coral reef bleaching, facts, hypotheses and implications. Glob Change Biol 2:495-509

> Greenstein BJ, Pandolfi JM (2008) Escaping the heat: range shifts of reef coral taxa in coastal Western Australia. Glob Change Biol 14:513-528

Hoegh-Guldberg O (1999) Climate change, coral bleaching and the future of the world's coral reefs. Mar Freshw Res 50:839-866

Hughes TP, Baird AH, Bellwood DR, Card M and others (2003) Climate change, human impacts, and the resilience of coral reefs. Science 301:929-933

Jaubert JM, Vasseur P (1974) Light measurements: duration aspect and the distribution of benthic organisms in an Indian Ocean coral reef (Tulear, Madagascar). Proc 2nd Int Coral Reef Symp 2:127-142

> Jury MR, Parker BA, Raholijao N, Nassor A (1995) Variability of summer convection over Madagascar: climate determinants of inter-annual scales. Int J Climatol 15:1323-1332

Kayanne H, Iijima H, Nakamura N, McClanahan TR, Behera S, Yamagata Y (2006) Indian Ocean Dipole index recorded in Kenyan coral annual density bands. Geophys Res Lett 33:L19709 doi:10.1029/2006GL027168

Kemp JM (1998) Zoogeography of the coral reef fishes of the Socotra Archipelago. J Biogeogr 25:919-933

Kremen C, Razafimahatratra V, Guillery RP, Rakotomalala J, Weiss A, Ratsisompatrarivo JS (1999) Designing the Masoala National Park in Madagascar based on biological and socioeconomic data. Conserv Biol 13:1055-1068

Kremen C, Cameron A, Moilanen A, Phillips SJ and others (2008) Aligning conservation priorities across taxa in Madagascar with high-resolution planning tools. Science 320:222-226

Laroche J, Ramananarivo N (1995) A preliminary survey of the artisanal fishery on coral reefs of the Tulear Region (southwest Madagascar). Coral Reefs 14:193-200

Lee T (2004) Decadal weakening of the shallow overturning circulation in the South Indian Ocean. Geophys Res Lett 31:L18305 doi:10.1029/2004GL020884

Liu G, Strong AE, Skirving W, Arzayus LF (2006) Overview of NOAA coral reef watch program's near-real time satellite global coral bleaching monitoring activities. Proc 10th Int Coral Reef Symp, Okinawa, p 1783-1793

Lutjeharms JRE (2006) The ocean environment off southeastern Africa: a review. S Afr J Sci 102:419-426

Machu E, Lutjeharms JRE, Webb AM, van Aken HM (2002) Satellite observations of upwelling on the continental shelf south of Madagascar. Geophys Res Lett 27: 3965-3968

> Maina J, Venus V, McClanahan TR, Ateweberhan M (2008) Modelling susceptibility of coral reefs to environmental stress using remote sensing data and GIS models in the western Indian Ocean. Ecol Model 212:180-199

McClanahan TR (2002) A comparison of the ecology of shallow subtidal gastropods between western Indian Ocean and Caribbean coral reefs. Coral Reefs 21:399-406

- McClanahan TR (2007) Testing for correspondence between coral reef invertebrate diversity and marine park designation on the Masoala Peninsula of eastern Madagascar. Aquat Conserv 17:409-419

> McClanahan TR, Maina J (2003) Response of coral assemblages to the interaction between natural temperature variation and rare warm-water events. Ecosystems 6:551-563

McClanahan TR, Shafir SH (1990) Causes and consequences of sea urchin abundance and diversity in Kenyan coral reef lagoons. Oecologia 83:362-370

McClanahan TR, Maina J, Moothien-Pillay R, Baker AC (2005) Effects of geography, taxa, water flow, and temperature variation on coral bleaching intensity in Mauritius. Mar Ecol Prog Ser 298:131-142

- McClanahan TR, Ateweberhan M, Sebastian CR, Graham NAJ, Wilson SK, Guillaume MMM, Bruggemann JH (2007a) Western Indian Ocean coral communities: bleaching responses and susceptibility to extinction. Mar Ecol Prog Ser 337:1-13

McClanahan TR, Ateweberhan M, Muhando C, Maina J, Mohammed SM (2007b) Effects of climate and seawater temperature variation on coral bleaching and mortality. Ecol Monogr 77:503-525

Pichon M (1978) Quantitative benthic ecology of Tulear reefs. In: Stoddart DR, Johannes RE (eds) Coral reefs: research methods. UNESCO, Paris, p 163-174

Precht WF, Aronson RB (2004) Climate flickers and range shifts of reef corals. Front Ecol Environ 2:307-314

Quartly GD, Srokosz MA (2004) Eddies in the southern Mozambique Channel. Deep-Sea Res II 51:69-83

Rayner NA, Parker DE, Horton EB, Folland CK, Alexander LV, Rowell DP, Kent EC, Kaplan A (2003) Global analyses of sea surface temperature, sea ice and night marine air temperature since the late nineteenth century. J Geophys Res D 108:4407

Reason CJC, Lutjeharms JRE (1998) Variability of the South Indian Ocean and implications for southern African rainfall. S Afr J Sci 94:115-123

Saetre R (1985) Surface currents in the Mozambique Channel. Deep-Sea Res Part A 32:1457-1467

Saji NH, Goswami BN, Vinayachandran PN, Yamagata T (1999) A dipole mode in the tropical Indian Ocean. Nature 401:360-363

Sakova IV, Meyers G, Coleman R (2006) Interannual variability in the Indian Ocean using altimeter and IX1-expendable bathy-thermograph (XBT) data: Does the 18-month signal exist? Geophys Res Lett 33:L20603 doi:10.1029/ 2006GL027117

Sall J, Lehmaan A, Creighton L (2001) JMP start statistics. Thomson Learning, SAS Inst., Pacific Grove, CA

Schils T, Coppejans E (2003) Spatial variation in subtidal plant communities around the Socotra Archipelago and 
their biogeographic affinities within the Indian Ocean. Mar Ecol Prog Ser 251:103-114

Sheppard CRC (1998) Biodiversity patterns in Indian Ocean corals, and effects of taxonomic error in data. Biodiv Conserv 7:847-868

Sheppard CRC (2003) Predicted recurrences of mass coral mortality in the Indian Ocean. Nature 425:294-297

Spalding MD, Ravilious C, Green EP (2001) World atlas of coral reefs. University of California Press, Berkeley, CA

Swallow JC, Fieux M, Schott F (1988) The boundary currents east and north of Madagascar. Part I. Geostrophic currents and transports. J Geophys Res C 93:4951-4962

Veron JEN, Turak E (2005) Zooxanthellate scleractinia of Madagascar. In: McKenna SA, Allen GR (eds) A rapid marine biodiversity assessment of the coral reefs of north-

Editorial responsibility: Hans Heinrich Janssen, Oldendorf/Luhe, Germany west Madagascar. Conservation International, Washington, DC, p 23-25

Wells FE (2005) Molluscs of northwest Madagascar. In: McKeena SA, Allen GR (eds) A rapid marine biodiversity assessment of the coral reefs of northwest Madagascar. Conservation International, Washington, DC, p 32-38

West JM, Salm RV (2003) Resistance and resilience to coral bleaching: implications for coral reef conservation and management. Conserv Biol 17:956-967

Winter A, Martin K (1990) Late Quaternary history of the Algulhas Current. Paleoceanography 5:479-486

Zinke J, Dullo WC, Heiss GA, Eisenhauer A (2004) ENSO and Indian Ocean subtropical dipole variability is recorded in a coral record off southwest Madagascar for the period 1659 to 1995. Earth Planet Sci Lett 228:177-194

Submitted: December 21, 2007; Accepted: December 4, 2008 Proofs received from author(s): March 16, 2009 